\title{
Learn English as Foreign Language using Language Laboratory of Elementary Education Program
}

\author{
Rohana \\ Elementary Education Program of Teacher Training Educationat University State of Makassar Indonesia
}

\begin{abstract}
This research deals with the improved the student writing and listening English as foreign language using language laboratory. Language laboratory used for get some benefits to improve the student' writing and listening. The aims of this research are: using language laboratory improves the student writing skill. This study employs experimental method. The sample of this research consists of 40 student of The Elementary Education Program in academic year 2013/2014. The data were analyzed using t- test to determine that significant different between pre-test and post-test. The result of the student' achievement in pre-test is low but the value of post-test mean account is high categories. This means learning of writing skill by using language laboratory to the elementary Education Program is getting improvement significantly and improve the student' achievement. The student has high interest in writing using language laboratories.
\end{abstract}

Keywords: Language Laboratory, Improve, listening, writing Skill

\section{Introduction}

Since language teaching is face in language laboratory, the activity we usually that do is writing and listening. Mastering writing and listening are not easy, the student need extra efforts to master the skills. English teacher are demanded to be more creative in presenting their material since it is a difficult skill to master. Student should taught in various ways that the student more interested and should have strong motivation in learning especially in writing reproduction, and practice their writing through listening by using a language laboratory.

Brian Sluster (2009) Responding to another's writing is always a chalenging task, Dankin (1973) states that language laboratory is a place for experiment and we try experiment on ourselves as intended it to do. Moreover, facilities are fully exemplify in a language laboratory in that every student has his own tape recorder equipped with earphones that enable the student to listen to the material recorded on his own tape without the rest of class. Furthermore learner receive individual attention from the teacher; each studentwork on his material, and responsible for his own performance. The language laboratory thus frees to the student and it is interest place to improve the student writing.

The students of Elementary Education Program said "writing and listening is difficult", there have seriously problem in writing English, they haven't mastering of writing technical, it"s average $25 \%$ the students mastering of writing rule, but $75 \%$ they haven't mastering of writing structure. They have the problem to writing clearly, to arrange of the some words to product sentences clearly. They did not understand about a rule of produce sentences arranged in particular order and linked together in certain ways. They have problems how to from a coherent whole of the sentences and from text, they are needs also to pay some attention to formal aspects; neat handwriting, correct spelling, and punctuation, as well as acceptable grammar and careful selection of vocabulary. This is because higher standards of language are normally demanded in writing than speech; more careful constructions, more precise and varied vocabulary, more correctness of expression in general. Also, slow and reflective nature of the process of writing in itself enables the writer to devote time and attention to formal aspects during the process of production. Manyaspects the student mastering in writing, there are problems for the PGSD students must be early given solution.

Why writing is difficult activity for most circumstances and accustomed us both in mother tongue and in the foreign language. We shall look at the problems which by writing under three headings; psychological, linguistic and cognitive. Speech is the natural and normal medium of communication for us in most circumstances and accustomed us both to having someone physically present when we use language and to getting feed back of some kind. Writing, on the other hand, is essentially solitary activity and that we are required to write on our own. Without interaction or the benefit of feedback, in self makes the act of writing difficult.

Based on the problem above, the writer formulates the research questions as follows: (1) Does the use of language laboratory of The Elementary Education Program improve the student" writting skill? (2) are the Elementary Education Program interested or not in writing by using Language laboratory?

The research purposed to find out improving of the student ${ }^{\text {te }}$ ability of writing reproduction by using of language laboratory and the studente interest in learn writing reproduction using language laboratory.In general the finding of this research is useful information for English teacher in teaching of writing in order that the teaching of writing in The Elementary Education Program is effective. The scope of research restricted using language laboratory in teaching English to improve the student ,writing reproduction. In this research, the writer limited research on writing reproduction in short stories, short sentences, short paragraph and short dialogue in their own version.

\section{Volume 4 Issue 12, December 2015}




\section{Writing Reproduction}

River (1967) Write in foreign language, the student must try systematically through five general stages development: Copying, Reproduction, Guided writing, recombination and composition. Reproduction is an artificial and useful stage in writing through ideas after listening or reading text. Having the student to preconceived the ideas from the text through listening, reading on occasion either rewriting it from memory or else. The student written reproduction in that the student writes something in his or her own. The teacher should creative in presenting it that the student develops their writing competence. George (1995) commented out that reproducing a piece of writing be exact reproduction of something read, heard on occasion either rewriting it from memory or else reproduction in that student rewrite something in their own words.

As the language skills in English, writing used to express idea. In writing, writes involved in the process of building the larger units of ideas from the small ones. Linked to form a piece of paragraph that be also linked together to form a larger unit of writing, that is a piece of composition.

Byrne (1984) expressed that: "Writing is clearly much more than the sounds. The symbols have arranged according to certain conventions, to form words, and words have to be arranged to form sentences. As a rule, productively of graphic symbols just a speech more than; the production of however, we are not writing just one sentence or a number of sentences arranged in a particular order and linked together in certain ways. Writing involves the encoding of messages of any kind; that is to translate through into language". Robert (1988) statement that, "Writing is one means of most activities". Richard (1999) writing is a way of expressing the thought from mind to print materials. From the definition above, we can conclude that writing is a way of expressing the thought or ideas, and writing activities involve encoding of message of some kind, which is too translated throughout into language.

\section{The Necessity of Writing}

Writing is a crucial means of communication. Usually writing becomes more appropriate when someone cannot express his or her ideas or feelings orally. Therefore, Borich Gary D. (1994). States that writing is essential to many aspects of social, practical and professional communication and those who have difficulties in expressing themselves in writing are handicapped in our society.

Doff, Adrian. (1989) define that writing helps students learn because it can a. reinforce the grammatical structure, vocabulary. b. student write have a chance to be adventuring with language, to go beyond what they have just learned, to say take a risk.

In school or college, writing is needed, without the ability to express you in writing; it will be difficult to pass as writing is an essential skill that must be mastered. The Component of writing: There six the components of writing. They are a) Content, b). Organization, c) Grammar, d) Vocabulary, e) Language use. f) Mechanics.
The Factors Affecting the Student Success in Learning:

1) Harmer (1991) motivation is some kind of internal drive that encourages somebody to pursue a course of action. Freeman. (1986) noted motivation help the student to understand the purpose of learning and divide the motivation in two categories they are intrinsic and extrinsic motivation. Intrinsic motivations there are desire of students themselves to learn, without the need for external inducements. (Example, the student won't be success in his/her school, he must be study hard) Extrinsic motivation: Those are rewards and inducements external to student. (Example, Mr. Ahmad advice his son must be study hard).

2) Brown, Douglas. (198) stated that interest as a subjectobject-attitude, concern of a condition involving a perception or idea in the attention and combination of intellectual and feeling curiously conditioned by experience. Heaton, (1988) defines an interest is as a feeling of preference connection of one"s own activities. The studente Interest from personal discipline in attending the English lesson. From this point of view, that the student's attitude may be formed because they have interest toward a certain lesson. There are three ways to measure the student ${ }^{\text {ee }}$ interest in writing reproduction using language laboratory as follows: 1. Student behavior; 2.The materials; 3. Teacheres performance.

\section{Language Laboratory and Reproduction}

Widdowson, (1985) Reproduction is an artificial and useful method in teaching writing trough composing ideas after listening to the language laboratory materials or recorded. The teachers should be creative in presenting this technique so that the student can develop them writing competence, such as selecting ideas. There are available materials (Even more challenging and enjoyable) setting approaching a classroom situation and guiding the student to be more active. Through the resemble dictation, the student has to listen to a text through recorded materials in the language laboratory to them. However, instead of being asked to take this down segment by segment which make dictation a somewhat artificial exercise, they listen to the complete text, short dialogue, short paragraph and sentences (usually three or more times) before they are asked to write. They are, required to reproduce a text they have heard. This Type of activity also involves a careful listening and the transformation of what was heard written form, however, it focuses much more on grasping the meaning of the text and in particular how sentences related to another.

\section{Research Method}

The method used in this research pre- experimental method, which consists of one group pretest- posttest design. It aims at obtaining the concept account for the extent encouragement of student writing productivity through using language laboratory.

This design above involved one group with pretest and posttest. The group has selected from population to receive treatment using language laboratory in learning writing reproduction. The population of the researches the Elementary Education Program There is three classes. Each

\section{Volume 4 Issue 12, December 2015}




\section{International Journal of Science and Research (IJSR) \\ ISSN (Online): 2319-7064 \\ Index Copernicus Value (2013): 6.14 | Impact Factor (2014): 5.611}

class consists of 40 students. The total number ofThe student is 120 students. The sample was in one class. They are class M.2.3. The writer took 40 students as the sample, so the total sample is 40 students. The data collected from this research tabulated into scoring classifications. The data achievement of the student's of writing reproduction The data will be collected through the writing test of reproduction of: (1) short story, (2) short paragraph, (3) short dialogues, and (4). sentences.

\section{Findings and Discussion}

The findings consist of the data obtained through achievement test of the written reproduction skill through using language laboratory. The data collected through questionnaire shown the student' attitude towards the study of written reproduction analyzed language laboratory. The discussion presents the description and interpretation of the finding. This research has been conducted for two months, 2 weeks for observation, 2 weeks for preparation of administration, 3 weeks for research application (pre-test, teaching, and post-test).

The findings that the researcher reported in this research based on the analysis of the data collected and the application of the methods explained in the previous. The findings were processed into two kinds by referring to the research questions formulated in the previous chapter, these are the following questions; (1) Does the use of language laboratory improve the student ${ }^{\text {ee }}$ reproduction skill using a language laboratory?, (2) Are the student interested in writing reproduction using a language laboratory?

The two questions above have formulated to find out the student' achievement taught the materials of written reproduction skill by using language laboratory and the student' attitude towards the written reproduction ability by using language laboratory, the result of the data has classified analyzed by using t-test formula of dependent sample.

\section{The student' achievement of English written reproduction skill taught by using language laboratory}

The student achievement of the written reproduction skill by using a language laboratory that out of 40 students, The rate percentage of the student account 4 (10 percent) student achievement high category or excellent, 19 (47,5 percent) student was classified good achievement category, 13 (32,5percent) student could achieve middle achievement category, and 4 (10 Percent) student got poor achievement category. The table presented below shows that the rate percentage of the student' account in writing reproduction skill taught by using a language laboratory got improved

The result of this research showed that the student' have account in post-test about 4 students or $10 \%$ obtained in high categories $(8,5-10)$, after treatment using language laboratory. The student accounts in the good categories about 19 students or $(47,5 \%)$ have accounts' (76- 85), 13 students $(32,5 \%)$ have accounts' (65-76) in the middle categories, and 4 students in low categories with accounts' (36-55).
The result of this research in pre-test showed 13 student (32,5\%) have account (0-35) they are classified lower, 20 student (50\%) have account (36-55) they are in low categories, and $7(17,5 \%)$ student in middle categories. The compare of both Pre-test and Post-test it have different account, the explanation of the data above means that the teaching of material of written reproduction skill by using language laboratory have got success significantly because the result of post-test account is higher than the student' account in pre-test.

The data of the student' account in writing reproduction ability taught by using the language laboratory technique above approves that the improvement of the student' achievement is great if it compare with the rate percentage of the student' account taught written reproduction skill by using conventional techniques, (the rate percentage of posttest comparison with the rate percentage of pre-test).

The data about rate percentage show that the use of language laboratory in teaching the materials of written reproduction skill may give effectiveness to improve the student' achievement and ability of the elementary education program. To find accounts of pre-test and post-test for 40 students on the written reproduction skill taught by using language laboratory.

The value of the student ' account in the post -test is stronger than the value of student' means account in pre-test, where $6.497>3.257$. This means that the teaching of materials of written reproduction skill by using a language laboratory to elementary education program is getting improved significantly, the data analysis of through the dependent $t$ test.

In this research, the dependent t-test used to analyze statically the data of pre-test and post-test. The dependent ttest used to know the student' achievement in teaching of written reproduction skill by using language laboratory. The purpose of using this statistic formula was to measure what the application of uses the language laboratory in teaching writing reproduction skill may in teaching writing reproduction skill improve the student' achievement significantly or not at level of $\alpha 0.05$. The calculating the data by using the formula of dependent t-test, the researcher.

The total account of pre-test is smaller when they compare with the total account of post-test, and of course, the total grade of students in post-test is higher when they compare with grade of pre-test. The calculating the data above, the result of dependent t-test value $=41.143$ and the t-table value $=2.021$ under the degree of freedom $39(\mathrm{df}=\mathrm{n}-1=$ $40-1=39$ ). The result of data analysis through dependent $t-$ test shows that the t-test value is smaller than compare with the t-table (1.301 2.021) under the degree of freedom 39 (df $=\mathrm{n}-1=40-1=39$ ).

This data be consulted with the data analysis of pre-test and post-test on the using language laboratory to improve the student' mean account of pre-test is 3.257 and the main account of post-test is 6.497. This means the value of 


\section{International Journal of Science and Research (IJSR) \\ ISSN (Online): 2319-7064}

Index Copernicus Value (2013): 6.14 | Impact Factor (2014): 5.611

student' mean account in post-test is greater than the account in pre-test where $60497>3.257$.

The technique of teaching the materials of written reproduction skill by using a language laboratory was able to change the student' ability and achievement better before. This is proved by the result of student' account in pre-test and post-test $(130.27>259.88)$.It means that the using language laboratory to improve the student' written reproduction skill in the process of learning and studying is better the traditional used before the research findings, the student' achievement taught the materials of written reproduction skill by using language laboratory is still far from the satisfaction.

\section{Discussion on the analysis of questionnaire}

The main purpose distributed the questionnaire to the student is to know the student' interest towards using a language laboratory in the teaching and learning process of materials for writing reproduction skill. The attitude of the student towards the study of written reproduction skill by using a language laboratory shown in the questionnaire indicates that much more of the student were interested in it.

The student opinion of the use of language laboratory in writing reproduction skill activity to improve the student's ability significantly for written and reproduce English of (38 or 95 percent) the student were not nervous to write English if the teacher used language laboratory and of course, they write English fluently. Skill shows that the student has motivation to improve their writing activity better before. All of ten student got high motivation to reproduce the English writing through using language laboratory (40 or 100 percent).

The student were enthusiastic to write English taught by using language laboratory they did not get any difficulties much to reproduce the writing skill, and the student was not boring to write English in language laboratory .In the other hand, they do the writing activity easily in the language laboratory guided by using many kinds of communication methods. The role of language laboratory in the writing activity helps them to improve their ability better, and all of the students (100 percent) think that the using of language laboratory gives a higher advantage for them to improve their written reproduction skill. This data indicated that the application of using language laboratory for written reproduction skill interest the student' motivation and the student' ability significantly.

The explanation above concluded that the teaching of materials for writing reproduction skill by using language laboratory is better to be applied because it improves the student' achievement significantly great the conventional technique applied before treatment and it improve the student motivation significantly.

\section{Conclusion and Suggestion}

Based on the research findings and discussion in the previous chapter, the study has come out with the following conclusions:
1) The achievement of the student of Elementary Education Program have taught the materials of written reproduction skill by using language laboratory is great significantly to be used. The result of the data analysis shows that the t-test value is smaller than the t-table value $(1.301<2.021)$. It means that the application of using language Laboratory to teach the materials of written reproduction skill is better after the treatment applied because it can improve the student' ability significantly.

2) The data from the questionnaire show that the use of language laboratory could motivate the student' interest in learning the written reproduction skill materials.

\section{Suggestion}

In the relation to the English subject, focuses on the written reproduction skill discussed and order to improve the study of writing skill activity to the student, the researcher deals with some suggestions as follows: (1). Teachers of English school are creative to apply many kinds of ways to teach the materials of writing skill. Since the student's achievement taught the written reproduction skill by using language laboratory improved the student' ability significantly, the researcher suggests the English teacher to apply the technique in the study of writing skill.. (2) The researcher recommends the readers of this thesis to use this technique (language laboratory use) to improve the student' achievement and ability, and to carry out a deeper investigation to examine using a language laboratory can improve the ability of student in written reproduction skill.

\section{References}

[1] Borich, Gary D. 1994. Observation Skills for Effective Teaching. New York: Macmillan Publishing Company

[2] Brown, Douglas. 1980. Principles of Language Learning and Teaching. USA:Prentice-hall, Inc.Englewood Cliffs.

[3] Byrne, Donn.1988. Teaching Writing skills. New eEdition. London and New York: Longman Group Ltd.

[4] Dankin, Julian. 1973. The Language Laboratory and simulation in action. London: Worburn Press

[5] Doff, Adrian. 1989 Teach English. London: Cambridge University Press.

[6] Hidalgo,George M.1995. Getting Started. Material Writers on Material Writing. Singapore: SEAMEO Regional language Center. I

[7] Heaton, J.B.1988.Writing English Language tests. New York: Longman.

[8] Janssen Mike. 1984. Applied Linguistics and the Learning and Teaching offoreign Language. London: Edward Arnold

[9] Jones, Ken. 1982. Simulation in Language Teaching. Cambridge: Cambridge Unversity Press.

[10]Lado, Robert. 1988. Teaching English across Culture: An Introduction for Theacher of English to Speakers of Other Languages. New York: Mc Graw Hill.

[11]Larsen, D. Freeman.1986. Techniques and Principles in Language Teaching. New York: Oxford University Press 


\section{International Journal of Science and Research (IJSR) \\ ISSN (Online): 2319-7064}

Index Copernicus Value (2013): 6.14 | Impact Factor (2014): 5.611

[12]Persulessy, George.1988.Listening Improvement Exercises For Student of English as a foreign Language. Forum. Vol XXV, 3 Juli 1988.

[13] Richards, J.C. and R.W.Schmidt. 1992. Language and Communication. London: Longman.

[14] Rivers, Temperly.J. 1987. EC. and R.W Essentials of English Language Teaching. London: Longman

[15]S. Punition.1977. Language Teaching Techniques. Third Edition. Victoria: University of Wellington.

[16] Tomlison, Brian.1998. Materials Development in Language Teaching. Cambridge: University press.

[17] Widdowson, H.G.1985. Teaching Language as Communication. Oxford: Oxford Unioversity Press. 